\title{
PENCABUTAN HAK POLITIK TERHADAP KORUPTOR DITINJAU DARI UNDANG-UNDANG HAK ASASI MANUSIA (Study Kasus Putusan Mahkamah Agung No.285 K/Pid.Sus/2015)
}

\author{
Ramma Hadi Saputra dan Trinas Dewi Hariyana \\ Fakultas Hukum Universitas Islam Kadiri \\ t.dewi.h@gmail.com
}

\begin{abstract}
Since the onset of reform, the issue of corruption eradication has always been a central theme in law enforcement in Indonesia. Corruption is a very serious matter, as corruption can harm the stability and security of the state and society. The application of the punishment of the revocation of political rights to the perpetrators of corruption by the judges gives pros and cons to the legal activists, because its implementation is not in accordance with the Law, as well as the existence of violations of Human Rights. The decision of the Supreme Court in the Case of Ratu Atut Cosiyah is a violation of Human Rights, because in its decision, the application of the revocation of political rights is not based on the Act. I.e. does not specify how long / time limits in the revocation of political rights. The research of the problem in this research is What is the judge's consideration in dropping the political rights to the perpetrator of corruption in Supreme Court decision Number $285 \mathrm{~K} /$ Pid.Sus / 2015 and how the Human Rights review in the revocation of political rights to the perpetrators of corruption in the Supreme Court decision Number $285 \mathrm{~K} / \mathrm{Pid}$.Sus / 2015 While the purpose of this study, namely to find out what judges judge consideration in depriving the political rights of perpetrators of corruption, and how the review of Human Rights Humans in depriving the political rights of perpetrators of corruption. The method used in this study is the normative juridical, which examines Supreme Court decisions Number 285 K / Pid.Sus / 2015. Sources of legal materials used in this study are primary, secondary, and non-legal sources of legal material. Techniques of collecting legal materials using literature review method or documentary study. The analysis is a qualitative analysis that aims to understand, interpret, and describe a reality. The author draws a deductive conclusion, drawing the conclusions of the things that are special, in which the two facts are bridged by theories
\end{abstract}

Keywords: Corruption, repeal of political rights, human rights. 


\begin{abstract}
ABSTRAK
Sejak bergulirnya reformasi, isu pemberantasan korupsi selalu menjadi tema sentral dalam penegakan hukum di Indonesia. korupsi merupakan masalah yang sangat serius, karena tindak pidana korupsi dapat membahayakan stabilitas dan keamanan negara dan masyarakat. Penerapan hukuman pencabutan hak politik kepada pelaku korupsi oleh hakim memberikan pro dan kontra pada kalangan aktifis hukum. Karena penerapannya tidak sesuai dengan Undang-Undang, serta adanya pelanggaran Hak Asasi Manusia. Putusan Mahkamah Agung dalam Kasus Ratu Atut Cosiyah adanya pelanggaran Hak Asasi Manusia. Karena dalam putusannya, penerapan pencabutan hak politik tidak berdasarkan Undang-Undang. yaitu tidak mencantumkan berapa jangka/batasan waktu dalam pencabutan hak politik. Adapan rumusan masalah dalam penelitian ini, apa pertimbangan hakim dalam menjatuhkan pencabutan hak politik terhadap pelaku korupsi dalam putusan Mahkamah Agung No.285 K/Pid.Sus/2015. Dan bagaimana tinjauan Hak Asasi Manusia dalam pencabutan hak politik terhadap pelaku korupsi dalam putusan Mahkamah Agung No.285 K/Pid.Sus/2015 Sedangkan tujuan penelitian ini, yaitu untuk mengetahui apa pertimbangan hakim dalam mencabut hak politik pelaku korupsi, serta bagaimana tinjauan Hak Asasi Manusia dalam mencabut hak politik pelaku korupsi. Metode yang digunakan dalam penelitian ini yaitu yuridis normatif, yang mengkaji putusan Mahkamah Agung No.285 K/Pid.Sus/2015. Sumber bahan hukum yang digunakan dalam penelitian ini yaitu sumber bahan hukum primer, sekunder, dan NonHukum. Teknik pengumpulan bahan hukum menggunakan metode kajian kepustakaan atau studi dokumenter. Analisis yang dilakukan adalah analisis secara kualitatif yaitu bertujuan memahami, menginterpretasikan, mendeskripsikan suatu realitas. Penulis menarik suatu kesimpulan secara deduktif, yaitu menarik kesimpulan dari hal-hal yang bersifat khusus, dimana kedua fakta tersebut dijembatani oleh teori-teori.
\end{abstract}

Kata Kunci : Korupsi, Pencabutan Hak Politik, Hak Asasi Manusia 


\section{Pendahuluan}

Indonesia merupakan negara yang berdasar atas Pancasila dan UndangUndang Dasar 1945 yang terimplementasi dalam peraturan perundangundangannya dimana segala hal yang berhubungan dengan Negara Kesatuan Republik Indonesia adalah berdasarkan atas aturan yang konkret, UndangUndang Dasar 1945 Pasal 1 ayat (3) menyatakan bahwa negara Indonesia berdasarkan atas hukum (Rechtstaat), tidak berdasarkan atas kekuasaan belaka (Machstaat). Ini berarti bahwa Indonesia adalah negara hukum yang demokratis berdasarkan pancasila dan Undang-Undang Dasar 1945, menjunjung tinggi hak asasi manusia dan menjamin semua warga negara bersamaan kedudukannya di dalam hukum dan pemerintah serta wajib menjunjung hukum dan pemerintahan itu dengan tidak ada kecualinya. ${ }^{1}$

Sejak bergulirnya reformasi, isu pemberantasan korupsi selalu menjadi tema sentral dalam penegakan hukum di Indonesia. Pendapat beberapa ahli mengenai pengertian tindak pidana korupsi berbeda-beda. Diantaranya berpendapat bahwa korupsi adalah penyimpangan dari tugas formal dalam kedudukan resmi pemerintah, bukan jabatan eksekutif tetapi juga legeslatif, partai politik, auditif, BUMN/BUMD hingga dilingkungan penjabat sektor swasta. Pendapat lainnya menitik beratkan tindakan korupsi atas dasar apakah tindakan seseorang bertentangan dengan kepentingan masyarakat, mempergunakan ukuran apakan tindakan tersebut dianggap koruftif oleh penjabat umum atau tidak. ${ }^{2}$

Bukan hanya di indonesia saja, juga dibelahan dunia yang lain tindak pidana korupsi selalu mendapatkan perhatian yang lebih khusus dibandingkan dengan tindak pidana lainnya. Fenomena atau gejala ini harus dapat dimaklumi, karena mengingat dampak negatif yang ditimbulkan oleh tindak pidana korupsi yang dapat mendistorsi berbagai kehidupan berbangsa dan bernegara dari suatu bangsa, bahkan juga terhadap kehidupan antar negara.

\footnotetext{
${ }^{1}$ Evi Hartati, Tindak Pidana Korupsi Edisi kedua, Jakarta: Sinar Gravika, 2008, hlm. 1.

${ }^{2}$ Surachmin dan Suhandi Cahaya, Srategi dan Teknik Korupsi, Jakarta: Sinar Gravika, 2011, hlm 10 .
} 
Politisi tidak lagi mengabdi kepada konstituenya, partai politik bukannya dijadikan alat untuk memperjuangkan kepentingan rakyat banyak, melainkan menjadi ajang untuk mengheruk harta dan ambisi pribadi. Padahal tindak pidana korupsi merupakan masalah yang sangat serius, karena tindak pidana korupsi dapat membahayakan stabilitas dan keamanan negara dan masyarakat, membahayakan pembangunan sosial, politik dan ekonomi masyarakat, bahkan dapat pula merusak nilai nilai demokrasi serta moralitas bangsa karena dapat berdampak membudayakan tindak pidana korupsi tersebut. Sehingga harus disadari meningkatnya tindak pidana korupsi yang tidak terkendali akan membawa dampak yang tidak hanya sebatas kerugian negara dan perekonomian nasional tetapi juga kehidupan berbangsa dan bernegara. $^{3}$

Penegakan hukum harus melindungi hak konstitusional warga negara untuk memperoleh jaminan dan perlindungan hukum yang pasti. Sedangkan dalam hukum pidana dimuat dalam Pasal 1 ayat (1) KUHP yang di terjemahkan sebagai asas legalitas. Dengan demikian, maka setiap tindakan dalam proses hukum harus mengacu pada suatu peraturan yang tertulis yang telah ditetapkan terlebih dahulu oleh perundang-undangan. ${ }^{4}$

Lahirnya Undang-Undang Nomor 31 Tahun 1999 juncto UndangUndang Nomor 20 Tahun 2001 tentang Pemberantasan Tindak Pidana Korupsi sebagai pengganti Undang-Undang Nomor 3 Tahun 1971 tentang Pemberantasan Tindak Pidana Korupsi dimaksud untuk mempercepat pemberantasan tindak pidana korupsi diindonesia. Adanya perubahan baik hukum materil maupun hukum formal serta ditingkatkannya ancaman pidana, dalam Undang-Undang Nomor 31 Tahun 1999 juncto Undang-Undang Nomor 20 Tahun 2001 tentang Pemberantasan Tindak pidana Korupsi merupakan upaya pemerintah untuk memusnahkan tindak pidana korupsi yang semakin bertambah. Akan tetapi, usaha pemerintah memberantas tindak pidana korupsi

\footnotetext{
${ }^{3}$ Ermansjah Djaja, Memberantas Korupsi Bersama KPK, Jakarta: Sinar Grafika, 2010 hlm. 3.

${ }^{4}$ Siswanto Sunarso, Filsafat Hukum Pidana Konsep, Dimensi, dan Aplikasi, Jakarta: PT Raja Grafindo Persada, hlm. 110.
} 
di Indonesia yang sudah mengakar keberbagai lapisan Indonesia, tidaklah mudah membalikkan telapak tangan. ${ }^{5}$

Berkaitan dengan pelakasanaan putusan pidana, Pasal 10 KUHP mengatur tentang jenis pidana yang dapat dijatuhkan kepada terdakwa tindak pidana korupsi yaitu pidana pokok dan pidana tambahan. Pidana pokok dalam pasal tersebut terdiri dari pidana mati, pidana penjara, pidana kurungan, dan pidana denda. Sedangkan pidana tambahan terdiri dari pencabuta hak-hak tertentu, perampasan barang-barang tertentu. Selain ketentuan pidana tambahan yang terdapat dalam KUHP, jenis pidana tambahan juga di rumuskan dalam Pasal 18 Ayat (1) Undang-Undang Nomor 31 Tahun 1999 Tentang Pemberantasan Tindak Pidana Korupsi antara lain :

1.1. Perampasan barang bergerak atau tidak bergerak atau yang berwujud atau yang tidak berwujud yang diperoleh dari hasil korupsi.

1.2. Pembayaran uang pengganti sebannyak-banyaknya.

1.3. Penutupan seluruh atau sebagian perusahaan untuk waktu paling lama 1 tahun

1.4. Pencabutan seluruh atau sebagian hak-hak tertentu atau penghapusan hak-hak tertentu. ${ }^{6}$

Pidana tambahan dalam hal pencabutan hak memilih dan dipilih barubaru ini mendapat perhatian dari para majelis hakim dalam putusannya terhadap perkara korupsi dikarenakan pidana denda dan pengembalian aset negara belum juga dirasakan mengakomodir rasa keadilan rakyat apalagi ketika terpidana korupsi tersebut kemudian mencalonkan menjadi anggota legislatif dan terpilih dalam pemilihan umum. ${ }^{7}$

Pada tahun ketahun, hukum positif Indonesia melakukan hukuman tambahan terhadap koruptor yaitu pencabutan hak politik terhadap penjabat publik yang melakukan korupsi. Salah satu kasus yang berkaitan dengan

${ }^{5}$ Ermansjah Djaja, Memberantas Korupsi ..., Op. cit., hlm 10.

${ }^{6}$ Evi Hartanti, Tindak Pidana korupsi ..., Op. cit., hlm 18.

${ }^{7}$ Al. Wisnubroto dan G. Widiartana, Pembaharuan Hukum Acara Pidana, Bandung: Citra Aditya Bakti, 2008, hlm. 1. 
pencabutan hak politik yaitu kasus Ratu Atut Cosyah yang melakukan penyuapan kepada mantan ketua Mahkamah Konstitusi yaitu Akil Mochtar. Majelis hakim tindak pidana korupsi memvonis Ratu Atut Cosyah hukuman 4 tahun penjara dan denda 200 juta dengan ketentuan apabila denda tidak dibayar, diganti dengan pidana kurungan selama 5 tahun. Putusan tersebut lebih ringan dari tuntutan jaksa Komisi Pemberantasan Korupsi yaitu 10 tahun penjara dan denda 250 juta subsider 5 bulan kurungan, ditambah pencabutan hak memilih dan dipilih dalam jabatan publik. Tetapi penuntut umum dari Komisi Pemberantasan Korupsi mengajukan banding karena hukuman tambahan pencabutan hak memilih dan dipilih dalam jabtan publik tidak dikabulkan. Dalam tingkat kasasi majelis hakim yang dipimpin hakim ketua Artidjo Alkostar mengabulkan hukuman tambahan serta memperberat hukuman Ratu Atut Cosyah dengan pidana penjara 7 (tujuh) tahun dan denda sebesar 200 juta rupiah dengan ketentuan apabila tidak dibayar diganti dengan pidana kurungan selama 6 (enam) bulan, menetapkan pencabutan hak terdakwa untuk dipilih dalam jabatan publik.

Hukuman tambahan tidak dapat dijatuhkan secara sendiri, melainkan harus dijatuhkan secara bersama-sama dengan suatu pidana pokok. Bagi seorang hakim dalam menjatuhkan putusan pidana terhadap terdakwa hakim wajib menetapkan arti yang tepat dari ketentuan pidana tersebut. ${ }^{8}$ Banyak pertimbangan yang menjadi dasar penjatuhan putusan, hukuman tambahan tersebut dirasa mendapat respon pro dan kontra diberbagai kalangan akademisi, praktisi, maupun aktifis Hak Asasi Manusia.

Sudah menjadi pengetahuan umum bahwa konsep Hak Asasi Manusia ditiap-tiap negara adalah berbeda, terlebih pada pelaksanaannya tidak bisa terlepas dari sistem perpolitikannya. Gunawan Muhammad dan Umar Kayam berpendapat, nilai budaya daerah pada tiap negara-negara yang berkembang bisa digali untuk menyokong unsur-unsur Hak Asasi Manusia. ${ }^{9}$ Untuk itu nilai asasi yang dimiliki oleh setiap bangsa perlu dipakai sebagai landasan pokok di

\footnotetext{
${ }^{8}$ D. Schaffmeister, dkk., Hukum Pidana, Bandung: Citra Aditya Bakti, 2007, hlm. 8.

${ }^{9}$ Masyur Effendi, Dimensi/Dinamika Hak Asasi Manusia dalam Hukum Nasional dan
} Internasional, Jakarta: Ghalia Indonesia, 2007, hlm. 47. 
dalam mengambil keputusan, sehingga tidak timbul suatu persepsi bahwa Hak Asasi Manusia semata-mata hasil budaya asing yang dipaksakan, justru semua manusia itu pada dasarnya adalah sama dimana Hak Asasi Manusia yang diakui disuatu negara adalah berdasarkan filterisasi dari nilai-nilai yang hidup di negara tersebut.

Sejak lahirnya NKRI tahun 1945, Negara telah menjunjung tinggi pelaksanaan Hak Asasi Manusia. Sikap tersebut Nampak dalam UndangUndang Nomor 39 Tahun 1999 Tentang Hak Asasi Manusia, yang memuat beberapa ketentuan tentang Hak Asasi Manusia warga Negara yaitu :

\subsection{Hak untuk hidup}

Hak untuk hidup ini meliputi hak untuk hidup, mempertahankan hidup dan meningkatkan taraf hidupnya, termasuk hak atas hidup yang tentram, aman, damai bahagia, sejahtera lahir dan batin serta hak atas lingkungan yang baik dan sehat. ${ }^{10}$

1.2. Hak berkeluarga dan menlanjutkan keturunannya

Pasal 10 Undang-Undang Nomor 39 Tahun 1999 menyatakan bahwa setiap orang berhak membentuk suatu keluarga dan melanjutkan keturunan melalui perkawinan yang sah yang hanya dapat berlangsung atas kehendak kedua calon suami dan istri yang bersangkutan sesuai dengan peraturan perundangan, dalam hal ini adalah Undang-Undang Nomor 1 Tahun 1974 tentang Perkawinan hal ini artinya bahwa perkawinan dilakukan atas niat suci tanpa paksaan, penipuan atau tekanan apapun dari siapapun terhadap calon istri atau calon suami. ${ }^{11}$

1.3. Hak mengembangkan diri perlindungan hak mengembangkan diri, bidang pendidikan, hak untuk memperoleh dan menyebarkan informasi, termasuk di dalammnya hak untuk berkomunikasi, dan hak untuk bersosialisasi. Undang-Undang ini memberikan jaminan bagi

\footnotetext{
${ }^{10}$ Philip Alston dan Franz Magnis-Suseno, Hak Asasi Manusia, Yogyakarta: PUSHAM UII, 2008, hlm. 257.

${ }^{11}$ Ibid, hlm 258.
} 
setiap orang untuk memperjuangkan hak pengembangan dirinya baik secara pribadi maupun kolektif untuk membagun dirinya, masyarakat lingkungannya serta bangsa dan negara dengan segala jenis sarana yang tersedia. ${ }^{12}$

1.4. Hak memperoleh keadilan.

Setiap orang mempunyai kedudukan yang sama dalam hukum. Hak-hak yang diatur dalam hak untuk memperoleh keadilan pada dasarnya adalah asas-asas dalam hukum pidana dan hukum acara tetapi tidak terbatas pada hukum pidana dan hukum acara. Di antaranya bahwa setiap orang berhak untuk memperoleh keadilan dengan mengajukan permohonan, pengaduan dan gugatan baik dalam perkara pidana, perdata, maupun administrasi. ${ }^{13}$

1.5. Hak atas kebebasan pribadi

Hak atas kebebasan pribadi merupakan salah satu hak yang paling mendasar bagi setiap orang karena menyangkut juga hak menentukan nasib sendiri. Dari berbagai hak yang dilindungi dalam Hak Asasi Manusia, hak atas kebebasan pribadi dan kebebasan berekspresi, mengeluarkan pendapat, berserikat dan berkumpul adalah hak yang paling penting Meskipun demikian, tidak berarti tidak ada hak-hak lain yang dilindungi yang berkaitan dengan hak atas kebebasan pribadi. Hak untuk tidak diperbudak, hak untuk memeluk agama, hak untuk dipilih dan memilih, hak kewarganegaraan dan hak bertempat tinggal merupakan hak-hak pribadi yang diatur oleh Undang-Undang ini. $^{14}$

1.6. Hak atas rasa aman

Hak atas rasa aman ini meliputi hak-hak yang dapat dilindungi secara fisik maupun psikologis. Hak ini di antaranya meliputi hak

\footnotetext{
${ }^{12}$ Ibid, hlm 259.

${ }^{13}$ Ibid.

${ }^{14}$ Ibid, hlm 261.
} 
suaka, hak perlindungan, hak rasa aman, hak rahasia surat, hak bebas dari penyiksaan, dan hak tidak diperlakukan sewenangwenang ${ }^{15}$

1.7. Hak atas kesejahteraan

Hak-hak atas kesejahteraan ini sangat diperjuangkan dengan gigih oleh bangsa-bangsa sosialis, sehingga kental sekali keberpihakan terhadap kaum buruh. Ini bukanlah hal yang buruk, karena dalam perkembangan dunia, masyarakat cenderung mengikuti pola industrialisasi dimana peran buruh sangatlah signifikan. Pada prakteknya seiring dengan kapitalisme yang terus berkembang, hak-hak kaum buruh diperlakukan dengan sewenang-wenang, sehingga wajar bilamana hak-hak atas kesejahteraan termasuk prioritas utama dalam perlindungan Hak Asasi Manusia. ${ }^{16}$

1.8. Hak turut serta dalam pemerintahan

Ada dua pembagian tentang hak turut serta dalam pemerintahan antara lain :

1.8.1. Hak untuk memmilih dan dipilih

Hak ini sangat terkait dengan hak di bidang politik, di antaranya keikutsertaan dalam pemilu, baik sebagai calon yang akan dipilih maupun sebagai pemilih. Hak memlilih dan dipilih ini haruslah sesuai hati nurani, bukan karena paksaan atau di bawah ancaman.

1.8.2. Hak untuk Mengajukan Pendapat

Melalui wakil rakyat di DPR, DPRD maupun DPD, masyaraka dapat berpartisipasi dalam pemerintahan. Termasuk mengajukan usulan, permohonan, pengaduan dan bahkan kritik terhadap pemerintah dalam rangka

\footnotetext{
${ }^{15}$ Ibid, hlm 265.

${ }^{16}$ Ibid, hlm 267.
} 


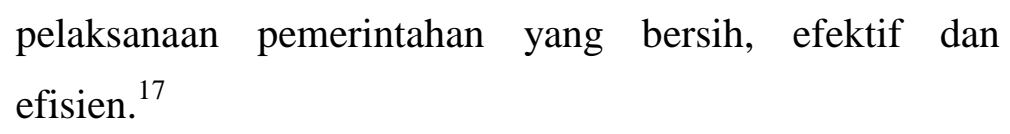

\subsection{Hak wanita}

Perempuan yang digolongkan dalam kelompok masyarakat rentan (vulnerable people) mendapat tempat khusus dalam pengaturan jaminan perlindungan hak asasi manusia dalam Undang-Undang Nomor 39 Tahun 1999 tentang Hak Asaasi Manusia ini. Pada umumnya hak yang diberikan kepada kaum perempuan sama dengan hak-hak lain seperti yang telah disebut di atas, hanya saja dalam bagian ini hak bagi kaum perempuan lebih dipertegas. Asas yang sangat mendasari hak asasi bagi perempuan di antaranya hak perspektif gender dan anti diskriminasi. Artinya kaum perempuan mempunyai kesempatan yang sama seperti kaum pria untuk mengembangkan dirinya, seperti dalam dunia pendidikan, pekerjaan, hak politik, kedudukan dalam hukum, kewarganegaraan, hak dan kewajiban dalam perkawinan. ${ }^{18}$

\subsection{Hak anak}

Hak anak meliputi banyak hal di antaranya hak atas nama dan kewarganegaraan sejak lahir, perlindungan dan perawatan khusus bagi anak berkebutuhan khusus, hak beribadah, berekspresi sesuai dengan usianya, hak untuk mengetahui dan dibesarkan orang tua, hak untuk dibesarkan, mendapat wali bila orang tua meningal sesuai putusan pengadilan, perlindungan hukum dari perlakuan buruk, hak untuk tidak dipisah dari orang tua secara paksa, hak pendidikan dan pengajaran, hak istirahat, hak berekreasi dengan teman sebaya, hak atas pelayanan kesehatan dan jaminan sosial, hak untuk tidak dilibatkan dalam konflik kekerasan, perlindungan

\footnotetext{
${ }^{17}$ Ibid, hlm 268.

${ }^{18}$ Ibid, hlm 269.
} 
dari eksploitasi ekonomi dan pelecehan seksual, tidak dijadikan sasaran penganiayaan. ${ }^{19}$

Dalam point 8 secara nyata Negara memberikan pengakuan kepada setiap warga negaranya untuk ikut serta dalam pemerintahannya yakni adanya hak politik, meliputi hak memilih dan dipilih dalam jabatan publik.

Pencabutan hak politik terhadap koruptor menjadi polemik yang masih banyak dipertanyakan oleh beberapa pihak, karena secara jelas dan sudah diatur dalam Undang-Undang Dasar 1945 yaitu hak turut serta dalam pemerintahan, dalam aturan tersebut sudah adanya pelanggaran Hak Asasi manusia kepada pelaku korupsi yang di cabut hak politiknya. Berdasarkan hal tersebut, maka diambil judul : 'Pencabutan Hak Politik Terhadap Koruptor Ditinjau dari Undang-Undang Hak Asasi Manusia (Study Kasus Putusan Mahkamah Agung No.285 K/Pid.Sus/2015),'

\section{Rumusan Masalah}

2.1. Apa pertimbangan hakim dalam mencabut hak politik pelaku korupsi (Putusan Mahkamah Agung No.285 K/Pid.Sus/2015).

2.2. Bagaimana tinjauan Hak Asasi Manusia terhadap pencabutan hak politik koruptor (Putusan Mahkamah Agung No.285 K/Pid.Sus/2015).

\section{Tujuan Penelitian}

3.1. Untuk menganalisa pertimbangan hakim dalam mencabut hak politik pelaku korupsi (Putusan Mahkamah Agung No.285 K/Pid.Sus/2015).

3.2. Untuk menganalisa tinjauan Hak Asasi Manusia terhadap pencabutan hak politik koruptor (Putusan Mahkamah Agung No.285 K/Pid.Sus/2015).

\section{Metode Penelitian}

\subsection{Jenis Penelitian}

Berdasarkan rumusan masalah dan tujuan penelitian maka metode penelitian yang digunakan adalah metode yuridis normatif. Metode penelitian yuridis normatif mengacu pada norma-norma hukum yang

\footnotetext{
${ }^{19}$ Ibid, hlm 270.
} 
terdapat dalam peraturan perundang-undangan dan putusan-putusan pengadilan serta norma-norma hukum yang ada dalam masyarakat. ${ }^{20}$

4.2. Pendekatan Penelitian

\subsubsection{Pendekatan Undang-Undang}

Pendekatan undang-undang (statute approach) dilakukan dengan menelaah semua undang-undang dan regulasi yang bersangkut paut dengan isu hukum yang sedang ditangani. Hasil dari telah tersebut merupakan suatu argumen untuk memecahkan isu yang dihadapi. $^{21}$

\subsubsection{Pendekatan Kasus}

Dalam pendekatan kasus (case approach), dilakukan dengan cara melakukan telah terhadap kasus-kasus yang berkaitan dengan isu yang dihadapi yang telah menjadi putusan pengadilan yang telah mempunyai kekuatan yang tetap. Dalam menggunakan pendekatan kasus, yang menjadi kajian pokok peneliti adalah ratio decidendi atau reasoning, yaitu pertimbangan pengadilan untuk sampai kepada suatu putusan. ${ }^{22}$

\subsection{Sumber Bahan Hukum}

\subsubsection{Bahan Hukum Primer}

Bahan hukum primer diperoleh dari Undang-Undang Dasar Republik Indonesia Tahun 1945, Kitab Undang-Undang Hukum Pidana dan Kitab Undang-Undang Acara Pidana, Undang-Undang Nomor 31 Tahun 1999 Tentang Pemberantasan Tindak Pidana Korupsi jo Undang-Undang Nomor 20 Tahun 2001 Tentang Perubahan atas Undang-Undang 31 Tahun 1999 Pemberantasan Tindak Pidana Korupsi, Undang- Undang Nomor 39 Tahun 1999 Tentang Hak Asasi Manusia dan Putusan Mahkamah agung No.285 K/Pid.Sus/2015

\footnotetext{
${ }^{20}$ Zainuddin ali, Metode Penelitian Hukum, Jakarta: Sinar grafika, 2011, hlm 105

${ }^{21}$ Peter Mahmud Marzuki, Penelitian Hukum, Cetakan Ketiga, Jakarta: Kencana, 2007

${ }^{22}$ Ibid, hlm 94.
} hlm 93. 


\subsubsection{Bahan Hukum Sekunder}

Yaitu bahan-bahan penelitian yang berasal dari literatur dan hasil penelitian para ahli sarjana yang berupa buku-buku yang berkaitan dengan pokok pembahasan dan internet.

\subsubsection{Bahan Non-Hukum}

Yaitu bahan-bahan penelitian yang diperoleh dari ensiklopedia dan sejenisnya yang berfungsi mendukung data primer dan sekunder seperti Kamus Besar Bahasa Indonesia dan internet.

\subsection{Teknik Pengumpulan Bahan Hukum}

Dalam pengumpul bahan hukum untuk penelitian yuridis normatif digunakan metode kajian kepustakaan atau studi dokumenter. Sehingga data yang digunakan dalam penelitian ini adalah data sekunder.

\section{Hasil Penelitian Dan Pembahasan}

\subsection{Pertimbangan Hakim dalam Mencabut Hak Politik Pelaku Korupsi (} Putusan Mahkamah Agung No.285 K/Pid.Sus/2015)

Negara Republik Indonesia yang berdasarkan atas hukum (rechtsstaat). ${ }^{23}$ Idealnya sebagai negara hukum yang menjunjung supermasi hukum Indonesia mempunyai kekuasaan yang tertinggi di dalam negara. ${ }^{24}$ Dalam menjalankan tugasnya aparatur negara itu diatur berdasarkan peraturan perundang-undangan yang berlaku, aparatur negara yang bertugas menjalankan penegakkan hukum, salah satu diantaranya adalah para hakim dipengadilan. ${ }^{25}$ G.P. Hoefnageles mengatakan bahwa sanksi dalam hukum pidana adalah semua reaksi terhadap pelanggaran hukum yang ditentukan undang-undang dimulai dari penahanan tersangka dan penuntutan terdakwa sampai pada penjatuhan vonis oleh hakim. ${ }^{26}$ 2013, hlm 41.

${ }^{23}$ Nurul Qamar, Hak Asasi Manusia dalam Negara Demokrasi, Jakarta: Sinar Grafika,

24 Ibid.

${ }^{25}$ Umar Said Sugiarto, Pengantar Hukum Indonesia, Jakarta: Sinar Grafika, hlm 90.

26 Teguh Prasetyo, 2010, Kriminalisasi dalam Hukum Pidana, Bandung: Nusa Media, 2013, hlm 79 . 
Salah satu ciri dari negara hukum adalah terdapat suatu kemerdekaan hakim yang bebas dan tidak dipengaruhi oleh kekuasaan eksekutif maupun kekuasaan legeslatif, kebebasan hakim tidak selalu harus diartikan bahwa hakim dapat melakukan tindakan sewena-wena terhadap suatu perkara yang diperiksanya. ${ }^{27}$

Pasal 24 UUD 1945, menyatakan:

(1) Kekuasaan kehakiman merupakan kekuasaan yang merdeka untuk menyelenggarakan peradilan guna menegakkan hukum dan keadilan.

(2) Kekuasaan kehakiman dilakukan oleh sebuah Mahkamah Agung dan badan peradilan yang berada di bawahnya dalam lingkungan peradilan umum, lingkungan peradilan agama, lingkungan peradilan militer, lingkungan peradilan tata usaha negara, dan oleh sebuah Mahkamah Konstitusi.

(3) Badan-badan lain yang fungsinya berkaitan dengan kekuasaan kehakiman diatur dalam undang-undang

Pasal 1 ayat (1) Undang-Undang Nomor 48 Tahun 2009 tentang Kekuasaan Kehakiman, menyatakan:

"Kekuasaan Kehakiman adalah kekuasaan negara yang merdeka untuk menyelenggarakan peradilan guna menegakkan hukum dan keadilan berdasarkan Pancasila dan Undang-Undang Dasar Negara Republik Indonesia Tahun 1945, demi terselenggaranya Negara Hukum Republik Indonesia."

Pengadilan adalah tugas yang dibebankan kepada pengadilan. Tugas utama pengadilan adalah sebagai tempat untuk mengadili atau memberikan putusan hukum dalam perkara-perkara yang diajukan kepadanya. Tindakan dari hakim adalah memberikan putusan atau vonis dan penetapan hakim. ${ }^{28}$

Penelitian ini menganalisis Putusan Mahkamah Agung No.285 K/Pid.Sus/2015 terhadap kasus Ratut Choisyah atas kasus penyuapan terhadap Akil Mochtar selaku hakim di pengadilan Mahkamah Konstitusi untuk memenangkan perkara kontitusi. Dalam putusan pengadilan

${ }^{27}$ Yesmil Anwar dan Adang, Sistem Peradilan Pidana, Bandung: Widya Padjadjaran, 2009, hlm 234.

${ }^{28}$ Ibid, hlm 91. 
tingkat pertama yang tidak menjatuhkan hukuman pidana tambahan pencabutan hak politik memilih dan dipilih dalam jabatan publik terhadap Ratut Choisyah serta dijatuhi hukuman pidana penjara 4 (empat) tahun dan pidana denda $\operatorname{Rp} 200.000 .000,00$ (dua ratus juta rupiah).

Dalam pengadilan tingkat banding hanya menerima permintaan banding dari penutut umum Komisi Pemberantasan Korupsi. kemudian diperkuat dalam putusan ditingkat kasasi hakim Mahkamah Agung mempertimbangkan hal-hal yang memberatkan dan hal-hal yang meringankan sebagai berikut :

5.1.1. Hal-hal yang memberatkan :

5.1.1.1. Terdakwa selaku Gubernur Banten, tidak memberikan contoh unutk mendukung progam pemerintah mewujudkan pemerintahan yang bersih dari kolusi, korupsi, dan nepotisme.

5.1.1.2. Perbuatan terdakwa mencederai Lembaga Peradilan utamanya Mahkamah Konstitusi.

5.1.1.3. Terdakwa tidak berterus terang atas perbuatannya.

5.1.2. Hal-hal yang meringankan :

5.1.2.1. Terdakwa berlaku sopan dipersidangan.

5.1.2.2. Terdakwa belum pernah dihukum.

Berikut ini putusan dalam tingkat kasasi yang memperberat putusan Ratut Chisyah dengan amar putusan sebagai berikut:

5.1.1. Menyatakan terdakwa $\mathrm{Hj}$. Ratu Atut Chosiyah, S.E. terbukti secara sah dan meyakinkan bersalah melakukan tindak pidana "KORUPSI SECARA BERSAMA-SAMA".

5.1.2. Menghukum terdakwa oleh karena itu dengan pidana penjara selama 7 (tujuh) tahun dan denda sebesar Rp200.000.000,00 (dua ratus juta rpiah) dengan ketentuan apabila denda tersebut tidak dibayar diganti dengan pidana kurungan selama 6 (enam) bulan. 
5.1.3. Menetapkan mencabut hak terdakwa untuk dipilih dalam jabatan publik.

5.1.4. Menetapkan masa penahanan yang telah dijalani terdakwa dikurangkan seluruhnya dari pidana yang dijatuhkan.

5.1.5. Memerintahkan agar terdakwa tetap ditahan.

5.1.6. Menetapkan agar seluruh barang bukti.

5.1.7. Membebankan terdakwa tersebut untuk membayar biaya perkara dalam semua tingkat peradilan dan biaya dalam tingkat kasasi ini ditetapkan sebesar Rp2.500 (dua ribu lima ratus rupiah).

Putusan Mahkamah Agung terhadap terdakwa Ratu Atut Cosiyah yang memberikan perhatian pada publik yaitu pencabutan hak politik dipilih dalam jabatan publik. Ratu Atut Chosiyah adalah terpidana kasus korupsi penyuapan kepada Hakim Kontitusi Akil Mohtar yang mendapat vonis pencabutan hak politik dipilih dalam jabatan publik. Padahal pidana tambahan tersebut sudah termuat cukup lama di dalam Undangundang Tindak Pidana Korupsi (TIPIKOR) dan Kitab Undang-undang Hukum Pidana (KUHP), tetapi para hakim tidak pernah menerapkannya dalam kasus-kasus korupsi.

Setiap putusan hakim pasti didasari oleh pertimbangan hukum yang sesuai dengan bukti yang didapat dari hasil penyidikan dan fakta yang terungkap di dalam persidangan. Putusan hakim juga harus sesuai dengan undang-undang dan keyakinan hakim yang tidak terpengaruh pada intervensi dari berbagai pihak lain, serta selanjutnya dapat dipertanggungjawabkan secara profesional kepada publik. Sudikno Mertokusumo mengemukakan bahwa putusan hakim adalah suatu pernyataan hakim, dalam kapasitasnya sebagai pejabat yang diberi wewenang itu oleh undang-undang, berupa ucapan di persidangan dan 
bertujuan untuk mengakhiri atau menyelesaikan suatu perkara atau suatu sengketa antara para pihak. ${ }^{29}$

Syarat utama bagi keputusan hakim itu adalah bahwa keputusan itu haruslah beralasan sehingga dapat dipertanggungjawabkan, bukan saja terhadap yang berkepentingan langsung, yaitu penuntut-penuntut umum dan terdakwa, tetapi juga terhadap masyarakat umumnya. Dengan keputusannya itu hakim harus menunjukkan bahwa hakim tidak telah mengambil keputusan dengan sewenang-wenang, bahwa peradilan yang ditugaskan kepadanya sebagai anggota dari kekuasaan kehakiman, selalu dijunjung tinggi dan dipelihara sebaik-baiknya, sehingga kepercayaan umum akan penyelenggaraan peradilan yang layak tidak akan sia-sia ${ }^{30}$

Penjatuhan pidana dan pemidanaan dapat dikatakan cermin peradilan pidana. Apabila proses peradilan yang misalnya berakhir dengan penjatuhan pidana itu berjalan sesuai asas peradilan, niscaya peradilan bisa dinilai apik. Apabila sebaliknya, tentu saja dinilai sebaliknya pula. Bahkan dapat dicap sebagai ada kemrosotan kewibawaan hukum.

Penjatuhan pidana dalam putusan pidana harus dipertimbangkan oleh hakim, dan putusan hakim bisa juga dibatalkan oleh Mahkamah Agung yang sebagaimana sudah diatur dalam Pasal 39 ayat (1) UndangUndang Nomor 48 Tahun 2009 tentang Kekuasaan Kehakiman yang menyatakan:

"Pengawasan tertinggi terhadap penyelenggaraan peradilan pada semua badan peradilan yang berada di bawah Mahkamah Agung dalam menyelenggarakan kekuasaan kehakiman dilakukan oleh Mahkamah Agung."

${ }^{29}$ Binsar Gultom, Kualitas Putusan Hakim Harus Didukung Masyarakat, Suara Pembaruan, 20 April 2006

${ }_{30}$ MH Tirtaamidjaja, Kedudukan Hakim dan Jaksa, Cetakan Kedua, Jakarta: Djambatan, 1962, hlm 69. 
Tindak pidana korupsi merupakan kejahatan luar biasa (extra ordinary crime). Hakim dalam memutus perkara Tindak Pidana korupsi harus mempertimbangkan sebab dan akibat dari putusan yang akan dijatuhkannya. Hakikatnya, teori pemidanaan tersebut ditransformasikan melalui kebijakan pidana (criminal policy) pada kebijakan legislatif. ${ }^{31}$

Mengenai vonis yang dijatuhkan Mahkamah Agung kepada terdakwa Ratu Atut Chosiyah yaitu pencabutan hak dipilihnya saja dalam jabatan publik, tetapi tidak dengan hak memilihnya, jadi ratu atut bisa tetap memilih sebagai hak warga negara. Tetapi hak pilihnya oleh hakim di cabut dalam vonis yang dijatuhkan.

Hakim menimbang putusan Ratu Atut Cosiyah dicabutnya hak pilih dalam jabatan publik melihat dari pemohon kasasi oleh penuntut umum Komisi Pemberantasan Korupsi. Bahwa dalam memori kasisi tersebut penuntut umum Komisi Pemberatasan Korupsi berpendapat bahwa pengadilan negeri dan pengadilan tinggi telah keliru dan salah menerapkan hukum atau menerapkan peraturan hukum tidak sebagaimana mestinya dalam menafsirkan ketentuan Pasal 18 UndangUndang Nomor 31 Tahun 1999 sebagaimana telah diubah dengan Undang-Undang Nomor 20 Tahun 2001 tentang Perubahan UndangUndang Nomor 31 Tahun 1999 tentang Pemberantasan Tindak Pidana Korupsi. Sehingga pengadilan negeri dan pengadilan tinggi tidak menjatuhkan pidana tambahan, khususnya mengenai pencabutan hak-hak tertuntu.

Dalam pengadilan tingkat pertama dan dikuatkan dalam tingkat banding hakim tidak menjatuhkan hukuman tambahan kepada Ratu Atut Cosiyah. Majelis hakim berpendapat terdakwa telah terbukti bersalah melakukan tindak pidana korupsi dan dijatuhi hukuman penjara serta masih dalam proses dalam perkara korupsi yang lain, sehingga dengan sendirinya akan terseleksi secara alamiah di masyarakat.

${ }^{31}$ Barda Nawawi Arief, Bunga Rampai Kebijakan Hukum Pidana, Bandung: Citra Aditya Bakti, 2002, hlm 128 
Penuntut umum pada Komisi Pemberantasan Korupsi berpendapat, pertimbangan tersebut tidak tepat karena terdakwa selaku Gubernur Banten merupakan penyelenggara negara memangku jabatan publik yang telah dipilih rakyat melalui proses demokrasi, namun dalam perjalananya terdakwa selaku Gubernur yang dipilih oleh rakyat tersebut telah mencederai nilai-nilai demokrasi itu sendiri terkait melakukan tindak pidana penyuapan kepada hakim Kontitusi terkait sengketa pemilukada Kabupaten Lebak Tahun 2013 yang di sidangkan di Mahkamah Konstitusi.

Walaupun seorang terdakwa telah dijatuhi pidana penjara oleh pengadilan, tidak semua lapisan masyarakat mengetahui khususnya dipedesaan. Sehingga jika terdakwa telah selesai menjalani pidana maka bisa saja yang bersangkutan kembali ke kancah politik atau menjadi penjabat publik dan masyarakat yang tidak mengetahui hal tersebut akan memillihnya kembali.

Penuntut umum pada Komisi Pemberantasan Korupsi juga berpendapat majelis hakim menjatuhkan pidana tidak hanya untuk kepentingan pembinaan terdakwa semata, melainkan seharusnya majelis hakim juga memperhatikan kepentingan masyarakat dan negara. Perbuatan terdakwa juga telah mencederai lembaga Mahkamah Konstitusi dan menodai demokrasi serta hak-hak rakyat.

Uraian di atas dapat simpulkan, pertimbangan penuntut umum pada Komisi Pemberantasan Korupsi telah benar. Mengingat bahwa korupsi merupakan kejahatan yang luar biasa yang bisa merusak kehidupan bangsa dan merampas hak hak rakyat. Sepatutnyalah hakim mempertimbangkan putusan melihat rasa keadilan dalam masyarakat.

Majelis hakim Mahkamah Agung sependapat dengan memori kasasi yang di ajukan oleh penuntut umum pada Komisi Pemberantasan korupsi. Majelis hakim membenarkan alasan-alasan tersubut karena pengadilan negeri dan pengadilan tinggi telah keliru dan salah menerapkan hukum. 


\subsection{Analisis Pencabutan Hak Politik Koruptor Perspektif Hak Asasi Manusia (Putusan Mahkamah Agung No.285 K/Pid.Sus/2015)}

Sebagai Negara Hukum maka Indonesia selalu menjunjung tinggi hak asasi manusia. Selalu menjamin segala hak warga negara bersamaan kedudukannya di dalam hukum dan pemerintah dengan tidak ada kecualinya. ${ }^{32}$

Putusan hakim merupakan mahkota dan puncak dari suatu perkara yang sedang diperiksa dan diadili oleh hakim tersebut. ${ }^{33}$ Dalam menerapkannya hakim harus mepertimbangkan dengan 3 aspek yaitu: yang pertama, aspek yuridis yang merupakan aspek yang paling utama dengan patokan kepada undang-undang, yang kedua aspek filosofis yang merupakan aspek yang mementingkan kebenaran dan keadilan, yang ketiga aspek sosiologis yaitu mempertimbangkan tata nilai budaya yang hidup dalam masyarakat. ${ }^{34}$

Pasal 1 Undang-undang Nomor 39 Tahun 1999 tentang Hak Asasi Manusia menyatakan:

"Hak Asasi Manusia (HAM) adalah seperangkat hak yang melekat pada hakikat dan keberadaan manusia sebagai mahluk Tuhan Yang Maha Esa dan merupakan anugerah-Nya yang wajib dihormati, dijunjung tinggi, dan dilindungi oleh negara,hukum, pemerintah dan setiap orang demi kehormatan serta perlindungan harkat dan martabat manusia".

Perkara korupsi terutama yang dituntut KPK hak terdakwa untuk diperlakukan secara fair untuk memperoleh keadilan sangat tidak penting. Perkara korupsi adalah kepentingan publik, karena itu keadilan publik menjadi satu-satunya ukuran. Hak asasi terdakwa tidak penting, yang penting dalah hak asasi publik. Sudah semestinya semua orang (kecuali pelaku), harus anti dan membenci korupsi, tetapi penegakan

${ }^{32}$ Andi Hamzah, Perbandingan Pemberantasan Korupsi di Berbagai Negara, cet-kedua, Jakarta: Sinar Grafika, 2005, hlm 2.

${ }^{33}$ Ahmad Rifai, Penemuan Hukum oleh Hakim dalam Perspektif Hukum Progresif, Jakarta: Sinar Grafika, hlm 94.

${ }^{34}$ Ibid, hlm 126. 
hukum harus tetap adil, dan menjujung tinggi hak asasi setiap orang termasuk terdakwa.

Pencabutan hak mengingatkan kembali adanya hukuman-hukuman yang merendahkan martabat manusia. Kesepakatan-kesepakatan internasional sudah menegaskan penghapusan terhadap hukuman yang merendahkan martabat manusia. Meniadakan atau mengurangi hak asasi terpidana kasus korupsi merupakan tindakan diskriminasi yang sewenang-wenang dan bertentangan dengan prinsip keadilan manusia. ${ }^{35}$

Hak konstitusional warga negara untuk memilih dan dipilih adalah hak yang dijamin oleh konstitusi, undang-undang dan Konvensi internasional, sehingga pembatasan penyimpangan dan peniadaan serta penghapusan akan hak dimaksud merupakan pelanggaran terhadap hak asasi warga negara"36

HAM berdasarkan hukum nasional maupun internasional dikelompokkan dalam konsep HAM yang bersifat derogable rights dan non derogable rights (International Convenant on Civil and Political Rights dengan ratifikasi Undang-Undang Nomor 12 Tahun 2005 dan UUD 1945 Pasal 28 I). Hak politik termasuk hak memilih dan dipilih dalam jabatan publik tergolong hak turut serta dalam pemerintahan. berdasarkan ICCPR yang telah diratifikasi oleh Indonesia dengan Undang-Undang Nomor 12 Tahun 2005 dan UUD 1945, hak politik atau hak untuk dipilih dalam jabatan publik tidak diatur dengan tegas tentang bisa tidaknya hak tersebut dikurangi/dicabut atau bisa di sebut dengan derogable.

Pasal 29 Ayat 2 DUHAM yang menyatakan bahwa pembatasan pemenuhan Hak Asasi Manusia hanya dapat dilakukan berdasarkan beberapa alasan berikut :

\footnotetext{
${ }^{35}$ www.hukumonline.com, Pencabutan Hak Tertentu, Diakses 2 mei 2017, Pukul 22.34.

36 www.ditjenpp.kemenkumham.go.id., Hak Kontitusi Warga Negara, Diakses 8 mei 2017, Pukul 06.00.
} 


\subsubsection{Dilakukan berdasarkan hukum}

5.2.2. Untuk menjamin pengakuan serta penghormatan yang layak bagi hak-hak dan kebebasan orang lain.

5.2.3. Untuk memenuhi syarat-syarat yang benar dari kesusilaan.

5.2.4. Demi tata tertib umum dalam suatu masyarakat demokrasi.

Pasal 12 ayat (3) International Covenant on Civil and Political Rights (ICCPR) atau dalam bahasa Indonesia disebut dengan Kovenan Internasional tentang Hak-hak Sipil dan Politik (KIHSP) menyatakan bahwa pembatasan pemenuhan HAM hanya dapat dilakukan dengan alasan berikut:

5.2.1. Ditentukan oleh Undang-Undang.

5.2.2. Menjaga keamanan nasional, ketertiban umum, kesehatan umum, dan kesusilaan.

5.2.3. Hak-hak dan kebebasan orang lain.

Pasal 21 dan pasal 22 ayat 2 International Covenant on Civil and Political Rights (ICCPR) atau dalam bahasa Indonesia disebut dengan Kovenan Internasional tentang Hak-hak Sipil dan Politik (KIHSP) menyatakan bahwa pembatasan pemenuhan Hak Asasi Manusia boleh dilakukan dengan alasan berikut:

5.2.1. Ditentukan oleh undang-undang.

5.2.2. Diperlukan dalam suatu masyarakat demokrasi.

5.2.3. Demi kepentingan keamanan nasional, keamanan dan ketertiban umum.

5.2.4. Menjaga kesehatan dan kesusilaan umum atau menjaga hak dan kebebasan orang lain.

Pasal 70 Undang-Undang No. 39 Tahun 1999 tentang Hak Asasi Manusia, menyatakan:

"Dalam menjalankan hak dan kewajibannya setiap orang wajib tunduk kepada pembatasan yang ditetapkan undang-undang dengan maksud untuk menjamin pengakuan serta penghormatan atas hak dan kebebasan orang lain dan untuk memenuhi tuntutan yang adil sesuai dengan pertimbangan moral, keamanan, dan ketertinban umum dalam suatru masyarakat demokratis". 
Pasal 73 Undang-Undang No. 39 Tahun 1999 tentang Hak Asasi manusia menyatakan:

"Dalam menjalankan hak dan kewajibannya setiap orang wajib tunduk kepada pembatasan yang ditetapkan undang-undang dengan maksud untuk menjamin pengakuan serta penghormatan atas hak dan kebebasan orang lain dan untuk memenuhi tuntutan yang adil sesuai dengan pertimbangan moral, keamanan, dan ketertinban umum dalam suatru masyarakat demokratis."

Sedangkan Pasal 28J ayat (2) UUD 1945, pembatasan pemenuhan Hak Asasi Manusia dapat dilakukan dengan alasan:

5.2.1. Ditetapkan dengan Undang-Undang.

5.2.2. Menjamin pengakuan serta penghormatan atas hak dan kebebasan orang lain.

5.2.3. Memenuhi tuntutan yang adil sesuai dengan pertimbangan moral, nilai-nilai agama, keamanan, dan ketertiban umum dalam suatu masyarakat demokratis.

Putusan Mahkamah Agung No.285 K/Pid.Sus/2015 terhadap kasus Ratut Choisyah dengan adanya pidana tambahan merupakan hukuman yang tepat bagi pelaku korupsi. Pidana tambahan juga sudah diatur jelas dalam Undang-Undang Nomor 1 Tahun 1946 tentang Kitab UndangUndang Hukum Pidana (KUHP) Pasal 10 yang menyatakan pidana tambahan berupa pencabutan hak-hak tertentu, dalam kasus Ratu Atut Cosiyah ini hakim menerapkan tentang pidana tambahan pencabutan hak politik.

Pasal 35 ayat (1) KUHP menyatakan hak-hak terdakwa yang dapat dicabut oleh hakim meliputi:

5.2.1. Hak memegang jabatan pada umumnya atau jabatan tertentu

5.2.2. Hak memasuki angkatan perang

5.2.3. Hak memilih dan dipilih dalam pemilihan yang diadakan berdasarkan aturan-aturan umum

5.2.4. Hak menjadi penasehat hukum atau pengurus atas penetapan pengadilan, hak menjadi wali, wali pengawas, 
pengampu atau pengampu pengawas atas orang yang bukan anaknya sendiri.

5.2.5. Hak menjalankan kekuasaan bapak, menjalankan perwalian atau pengampuan atas anak sendiri, dan

5.2.6. Hak menjalankan mata pencaharian tertentu.

Pasal 38 KUHP juga menjelaskan batasan waktu pencabutan hak politik koruptor, yang menyatakan:

5.2.1. Apabila hakim menjatuhkan pidana mati atau penjara seumur hidup, lamanya pencabutan seumur hidup.

5.2.2. Apabila hakim menjatuhkan pidana penjara waktu tertentu atau pidana kurungan, lamanya pencabutan hak paling sedikit 2 tahun dan paling banyak 5 tahun lebih lama dari pidana pokoknya.

5.2.3. Apabila hakim menjatuhkan pidana denda, lamanya pencabutan paling sedikit 2 tahun dan paling banyak 5 tahun.

5.2.4. Pencabutan hak mulai berlaku pada hari putusan hakim dijalankan.

Mengenai kasus Ratu Atut Cosiyah dalam uraian diatas dapat disimpulkan, penjatuhan pidana tambahan berupa penerapan pidana pencabutan hak dipilih dan memilih dalam jabatan publik terhadap terdakwa pelaku korupsi tidak ada pembatasan sampai kapan pidana tambahan tersebut dijatuhkan. Hal ini melanggar ketentuan Pasal 38 KUHP, yang mengatur pembatasan terhadap penjatuhan pidana pencabutan hak tertentu. Dalam Pasal 38 Ayat 2 KUHP menyebutkan apabila hakim menjatuhkan pidana penjara waktu tertentu atau pidana kurungan, lamanya pencabutan hak paling sedikit dua tahun dan paling banyak lima tahun lebih lama dari pidana pokoknya.

Pelanggaran Hak Asasi Manusia tidak terjadi jika penerapannya sesuai dengan peraturan dalam Undang-Undang Hak Asasi Manusia. Dalam pasal 70 dan 73 Undang-Undang Nomor 39 Tahun 1999 tentang 
Hak Asasi Manusia menyatakan, Hak Asasi Manusia dapat dibatasi berdasarkan Undang-Undang untuk menjamin pengakuan dan penghormatan terhadap Hak Asasi Manusia serta kebebasan dasar orang lain, kesusilaan, kepentingan umum, dan kepentingan bangsa. Kasus Ratu Atut Cosiyah dalam putusannya telah keliru dalam menerapkan hukuman pencabutan hak dipilihnya, karerna sudah jelas diuraikan diatas bahwa pencabutan hak-hak tertentu sudah dibatasi jangka waktu oleh Undang-Undang yaitu Pasal 38 KUHP. Dengan demikian penjatuhan putusan tersebut melanggar HAM karena tidak sesuai dengan Pasal 70 dan 73 Undang-Undang Nomor 39 Tahun 1999 tentang Hak Asasi Manusia karena pembatasan pencabutan hak dipilihnya tidak berdasarkan Undang-Undang yaitu tidak sesuia dengan Pasal 38 KUHP.

Secara sosiologis hakim juga harus mempertimbangkan kepentingan pribadi terpidana apalagi berkaitan dengan Hak Asasi Manusia. Akibatnya putusan ini adanya pelanggaran Hak Asasi Manusia terhadap terpidana jika tidak ada pembatasan/jangka waktu pencabutan hak tersebut.

Penjatuhan pidana tambahan dapat disimpulkan bahwa, penjatuhan pidana pencabutan hak politik terhadap terdakwa pelaku korupsi tidak berpotensi melanggar Hak Asasi Manusia jika penerapan putusannya sesuai dengan Undang-Undang Hak Asasi Manusia.

Kasus Ratu Atut Cosiyah juga menceridai pengadilan Kontitusi di Indonesia, tindakan pelaku juga merugikan orang banyak karena menyangkut seluruh wilayah Banten yang secara tidak langsung dibohongi atas pemilihan gubernur. Terpidana juga terbukti secara sah dan meyakinkan bersalah tindak pidana korupsi dengan menyuap hakim Kontitusi Akil Mochtar. Terpidana sebagai Penjabat publik menyalahgunakan kekuasaan untuk kepentingan pribadi dan kelompoknya. 


\section{Kesimpulan}

6.1. Putusan Mahkamah Agung kepada terdakwa Ratu Atut Chosiyah yaitu pencabutan hak dipilihnya saja dalam jabatan publik, tetapi tidak dengan hak memilihnya, jadi Ratu Atut Cosiyah bisa tetap memilih sebagai hak warga negara. Dalam memori kasasi yang telah diajukan oleh penuntut umum Pemberantasan Tindak Pidana Korupsi mempertimbangkan alasan pengadilan negeri dan pengadilan tinggi tidak menerapkan hukuman tambahan karena pengadilan negeri dan pengadilan tinggi telah keliru menerapkan hukum tidak sebagaimana mestinya. Penuntut umum pada Komisi Pemberantasan korupsi berpendapat bahwa terdakwa selaku gubernur Banten merupakan penyelenggara pemangku jabatan publik yang telah dipilih oleh rakyat tersebut telah mencederai nilai-nilai demokrasi itu sendiri, serta merampas hak-hak rakyat. Jadi pertimbangan hakim Mahkamah Agung menjatuhkan pidana tambahan pencabutan hak dipilinya saja sudah tepat karena melihat dari pertimbangan memori kasasi yang telah diajukan penuntut umum pada Komisi Pemberantasan Korupsi, Mahkamah Agung juga bisa membatalkan putusan pengadilan dibawahnya sesuai aturan yang berlaku.

6.2. Penerapan pidana tambahan pencabutan hak memilih dan dipilih dalam jabatan publik yang termuat dalam putusan Mahkamah Agung No.285 K/Pid.Sus/2015 yang dijatuhkan oleh Ratu Atut Cosiyah kurang tepat. Karena tidak ada pembatasan sampai kapan pidana tambahan tersebut dijatuhkan. Hal ini melanggar ketentuan Pasal 70 dan 73 UndangUndang No. 39 Tahun 1999 tentang Hak Asasi Manusia, karena penerapan pencabutan hak tidak berdasarkan Undang-Undang. Karena Pasal 38 KUHP menyebutkan apabila hakim menjatuhkan pidana penjara waktu tertentu atau pidana kurungan, lamanya pencabutan hak paling sedikit dua tahun dan paling banyak lima tahun lebih lama dari pidana pokoknya. 


\section{DAFTAR PUSTAKA}

\section{Literatur Ilmiah}

Ali, Zainuddin, Metode Penelitian Hukum, Jakarta: Sinar grafika, 2011.

Arief, Barda Nawawi, Bunga Rampai Kebijakan Hukum Pidana, Bandung: Citra Aditya Bakti, 2002.

Al. Wisnubroto dan G. Widiartana, Pembaharuan Hukum Acara Pidana, Bandung: Citra Aditya Bakti, 2008.

Djaja, Ermansjah, Memberantas Korupsi Bersama KPK, Jakarta: Sinar Grafika, 2010.

D. Schaffmeister, dkk., Hukum Pidana, Bandung: Citra Aditya Bakti, 2007.

Effendi, Masyur, Dimensi/Dinamika Hak Asasi Manusia dalam Hukum Nasional dan Internasional, Jakarta: Ghalia Indonesia, 2007.

Gultom, Binsar, Kualitas Putusan Hakim Harus Didukung Masyarakat, Suara Pembaruan, 20 April 2006

Hartati, Evi, Tindak Pidana Korupsi Edisi kedua, Jakarta: Sinar Gravika, 2008.

Hamzah, Andi, Perbandingan Pemberantasan Korupsi di Berbagai Negara, cet-kedua, Jakarta: Sinar Grafika, 2005.

Marzuki, Peter Mahmud, Penelitian Hukum, Cetakan Ketiga, Jakarta: Kencana, 2007.

MH Tirtaamidjaja, Kedudukan Hakim dan Jaksa, Cetakan Kedua, Jakarta: Djambatan, 1962.

Philip Alston dan Franz Magnis-Suseno, Hak Asasi Manusia, Yogyakarta: PUSHAM UII, 2008.

Prasetyo, Teguh, Kriminalisasi dalam Hukum Pidana, Bandung: Nusa Media, 2010.

Qamar, Nurul, Hak Asasi Manusia dalam Negara Demokrasi, Jakarta: Sinar Grafika, 2013.

Rifai, Ahmad, Penemuan Hukum oleh Hakim dalam Perspektif Hukum Progresif, Jakarta: Sinar Grafika.

Surachmin dan Suhandi Cahaya, Srategi dan Teknik Korupsi, Jakarta: Sinar Gravika, 2011.

Sunarso, Siswanto, Filsafat Hukum Pidana Konsep, Dimensi, dan Aplikasi, Jakarta: PT Raja Grafindo Persada,.

Said Sugiarto, Umar, Pengantar Hukum Indonesia, Jakarta: Sinar Grafika.

Yesmil Anwar dan Adang, Sistem Peradilan Pidana, Bandung: Widya Padjadjaran, 2009.

\section{Undang-Undang}

Undang-Undang Dasar Republik Indonesia Tahun 1945.

Undang-Undang Nomor 1 Tahun 1946 Tentang Kitab Undang-Undang Hukum Pidana.

Undang-Undang Nomor 31 Jo Undang-Undang Nomor 20 Tahun 2001 tentang Pemberantasan Tindak Pidana Korupsi. 
Undang-Undang Nomor 30 Tahun 2002 Tentang Komisi Pemberantasan Tindak Pidana Korupsi.

Undang-Undang Republik Indonesia Nomor 39 Tahun 1999 Tentang Hak Asasi Manusia.

Undang-Undang Nomor 48 Tahun 2009 tentang Kekuasaan Kehakiman

Undang-undang Nomor 12 Tahun 2005 tentang Pengesahan International Covenant On Civil And Political Rights (Kovenan Internasional tentang Hak-Hak Sipil dan Politik).

TAP MPR Nomor XVII/MPR/1998

Universal Declaration of Human Rights (Deklarasi Universal Tentang Hak Asasi Manusia ) (DUHAM).

\section{Internet}

www.kompasiana.com/amp/rohlimohamad/, "hak-pilih-warga-negara-sebagaisarana-pelaksanaan-kedaulatan -rakyat-dalam-pemilu", Akses 20 April 2017, Pukul 08.10.

www.hukumonline.com, "Pencabutan Hak Tertentu", Akses 2 mei 2017, Pukul 22.34.

www.ditjenpp.kemenkumham.go.id., "Hak Kontitusi Warga Negara", Akses 8 mei 2017, Pukul 06.00.

Putusan Pengadilan

Komisi Pemberantasan Korupsi, Hj. Ratu Atut Cosiyah, Putusan Mahkamah agung No.285 K/Pid.Sus/2015. 